\title{
The Analysis of Renal Anatomy and Histological Changes of Green Iguana (Iguana Iguana) After Feeding With Red Spinach (Amaranthus tricolor L.)
}

\author{
Annita Vury Nurjunitar', Fika Yuliza Purba', Wahyuni ${ }^{2}$, Ismartoyo ${ }^{3}$, Dwi Kesuma Sari ${ }^{*}$ \\ 1Study Program of Veterinary Medicine, Veterinary Profession Education Program, Veterinary Teaching \\ Clinic, Faculty of Medicine, Hasanuddin University, Jl. Perintis \\ Kemerdekaan Km. 10, Makassar, South Sulawesi, 90245, Indonesia, Ph. +62-85299279988 \\ ${ }^{2}$ Disease Investigation Center of Maros, JI. Dr. Ratulangi, Maros, South Sulawesi, 90514, Indonesia \\ ${ }^{3}$ Faculty of Animal Science, University of Hasanuddin, Jl. Perintis \\ Kemerdekaan Km. 10, Makassar, South Sulawesi, 90245, Indonesia
}

*Corresponding author: Dwi Kesuma Sari (e-mail: dwiksari@vet.unhas.ac.id)

\begin{abstract}
Iguana breeders usually used red spinach as a feed for iguanas. However, several studies have indicated that red spinach contains oxalate and purine which are harmful if consumed at a certain level because they can interfere with kidney function. This study aimed to investigate the change of anatomy and histology of green iguana (Iguana iguana) kidney after feeding with red spinach. Twelve iguanas were used in this study and were divided into four groups in accordance to the dose level of red spinach $(100 \%, 75 \%, 50 \%$ and $25 \%$, namely group I to IV, respectively). The red spinach was given for 30 days through the nasogastric intubation. The effect of red spinach administration was observed through the anatomy and histological changes. The results were statistically analyzed with One Way ANOVA with $p<0.05$ was considered significant, and Post Hoc Test. The histopathology change of the kidney was analyzed descriptively. The administration of red spinach in iguanas caused some anatomy changes of the kidney; such as the enlargement of iguana's kidney. The histological findings included the enlargement of the glomerulus, capsular space constriction, hydropic degeneration, tubular dilation, necrosis, and formation of connective tissue (fibrosis), uric acid crystal sediment (gout), oxalate crystal, and lymphocyte infiltration. Among four different dose levels of red spinach, $100 \%$ of red spinach caused the highest damage to the iguana's kidney. The significant change grew as the increasing dose of red spinach that was given to the green iguanas' bodies. Red spinach caused changes in anatomy structure as well as kidney histology of green iguanas. Severe damages occurred in the treatment group III, moderate damage occurredin the treatment group II, and light damage occurred in the treatment group I.
\end{abstract}

Key words: Green iguana, Red spinach, Kidney, Anatomy change, Histology change

Copyright $\odot 2019 \mathrm{JRVI}$. All rights reserved.

\section{Introduction}

Formerly reptiles are considered scary, should be avoided even destroyed, because most reptiles are considered dangerous and venomous wild animals. Recently this view has changed, and many people love reptiles because of their uniqueness or color variations. The variety and 
uniqueness of reptiles then attract the attention of animal lovers to breed and reproduce them (Putranto et al., 2013).

Green iguanas are one of the herbivorous lizards which are popular as pets. The green iguana has a large body, semi-arboreal to arboreal (living in a tree) derived from the New World (American) Iguanidae family. The green iguana has a relatively long tail (with three times the length of the body) and permanent waves (gum crest located below the throat). The iguana species has one or more large scales under the tympanum (eardrum) and large jaws in the nuchal (neck) and the spine (back). The male and female Posts have one row of femoral pores below the thighs (Vosjoli et al., 2012). Iguanas have a pair of dark reddish-brown lobed kidney (Girling, 2003; Hernandez-Diver, 2003). In several lizards such as green iguanas, the kidney is located on the pelvis, it is attached to the dorsal of the body wall, and kidney caudal expands to the beginning of the tail (Girling, 2003). Reptilian kidney normally has only a few thousands of nephrons (Hernandez-Diver, 2003). The excretion of the major reptile discharges nitrogenous waste in the form of uric acid because the solubility of the substance in the air is lower when compared with ammonia or urea. This uric acid can be excreted in the form of a white paste with very little water loss so it can help save water (Anonymous, 2013).

Knowledge about reptiles, especially green iguana (Iguana iguana) is still limited. Various problems in raising green iguanas caused a health problem. One of them is kidney disorder which is caused by diet mistake. Some iguana breeders use red spinach as a feed for iguanas. However, the breeders are not aware of the effects of using red spinach on iguanas. Spinach contains various nutrients needed by the body. Spinach contains vitamin $A, B, C, E$, and $K$, iron, manganese, phosphorus, zinc, protein, purine, fat, carbohydrates, flavonoids, amarantin, potassium, selenium, niacin, beta-carotene, omega-3 fatty acids, fiber, neoxanthin, violaxanthin, lutein, zeaxanthin, angiotensin, and antioxidants (Nuraini, 2014). Besides containing many nutrients, spinach also contains chemical compounds that are negative, such as oxalic acid. Oxalic acid and its salts are water soluble that can be harmful because these compounds are toxic (Fitriani et al., 2016). Inside the body, oxalate will bind to calcium and form crystals thus called calcium oxalate. The crystals will be settled, and once it piles up, it will grow and form the kidney stones (Lingga, 2010). The purine content of uric acid metabolism in the blood will increase and cause a build-up of uric acid crystals (Zakhia, 2015).

Although iguanas domestication has been done for a long time, there were not many types of research about iguanas. Therefore, the researcher tries to perform research to know the anatomy structure and kidney histology change of green iguana after feeding with red spinach. Moreover, it also meant to know the effect of feeding red spinach towards kidney histology changing of green iguanas.

\section{Materials and Methods}

Study area and animals: This study was conducted in May 2016 at the Animal Diagnostic Clinic Laboratory of Medical Faculty at Hasanuddin University. The samples that were used in this study were twelve 2-3 months green iguanas (Iguana iguana) with 28-32 grams weight. The samples were healthy iguanas which came from the same parent and cultivation. The iguanas were placed in the individual plastic cages where the dimension was $35 \times 30 \times 25 \mathrm{~cm}^{3}$. The floor was layered with paper to make the stools cleaning easily; tree branches were for climbing as well as drinking water container. The iguanas were firstly adapted for a week, placed in the same condition, fed with the same regular food which was collard, and drunk in ad libitum way. The housing and nursing of these animals have been properly complied with the guidelines for animal experiments, Medical Faculty, Hasanuddin University. 


\section{Materials preparation}

The regular food was collard that given 6 grams/ day/ head for the control group, 4.5 grams/ day/ head for treatment group I, and 3 grams/ day/ head for treatment group II.Red spinach: The red spinach was given in dosage for 1.5 grams/ day/ head for treatment group l, 1.3 grams/ day/ head for treatment group II, and 6 grams/ day/ head for treatment group III. The spinach was dissolved in water.

\section{Experimental design}

This study used 12 green iguanas which were divided into 4 groups with three iguanas each: Control Group: $\mathrm{P}_{0}: 100 \%$ collard @ 6 grams/ day/ head, Group I: $\mathrm{P}_{1}: 75 \%$ collard $+25 \%$ red spinach @ 4.5 grams/ day/ head +1.5 grams/ day/ head, Group II: $\mathrm{P}_{2}: 50 \%$ collard $+50 \%$ red spinach @ 3 grams/ day/ head + 3 grams/ day/ head, Group III: $\mathrm{P}_{3}: 100 \%$ red spinach @ 6 grams/ day/ head. The feeding was given per oral, and red spinach was given through the nasogastric tube to prevent the food to be regurgitated in a certain amount every time the feeding begins. The treatment was performed twice a day at 08:00 A.M and 01:00 P.M for 30 days. The iguanas were weighted once a week to fit the food dose with the iguanas' weight. Moreover, the drink was also taken care of in ad libitum way. After the 30 day treatment period was completed, the entire iguanas were euthanized on the $31^{\text {st }}$ day.

\section{Histology preparation}

The kidney organ sample were fixated on $10 \%$ formalin solution. The organ samples were taken from the sacrificed iguanas. Then, the organ samples were dehydrated and started from $70 \%, 80 \%, 90 \%, 95 \%$, and $100 \%$ concentration. After that, they were clearing in xylol before they were finally embedded in paraffin. The tissue in paraffin was cutwith $5 \mu$ m thickness using microtome. The sample was then stained using hematoxylin and eosin (HE) to see the structure of the tissue which was presumed to undergo pathologic change (Bacha and Bacha, 2000). The observation was done under a microscope, with 10 and 16 times subjective lens zoom as well as 10, 40, and 100 times objective lens. Images were taken by using adigital camera. Immersion oil was usedat 100 times magnification. Then, the images of the green iguanas' kidneys were compared.

\section{Technique of data analysis}

The quantitative data was analyzed by comparing the treatment groups based on the given red spinach dose with Mitchel's method that could be seen table 1 and 2. While the data achieved from the anatomy observation was analyzed descriptively, One way ANOVA statistic, and if there was asignificant difference $(P<0.05$ was considered as significant), then this analysis proceeded to Post Hoc test for comparison among groups. The green iguanas' kidney histopathology preparation observation was analyzed descriptively.

Table 1: Kidney glomerulus damage levels (Ghufron, 2001)

Damage levels Explanation

\begin{tabular}{ll}
\hline Normal & $\begin{array}{l}\text { Normal, the core is clear, the shape is round } \\
\text { Light }\end{array}$ \\
Glomerulus enlargement,+ capsular space constriction,+ hemorrhage + \\
Goderate & $\begin{array}{l}++ \\
\text { Glomerulus enlargement }++, \text { capsular space constriction }++, \text { hemorrhage } \\
\text { hemorrhage }+++\end{array}$ \\
Severe &
\end{tabular}


Explanation :

$$
\begin{array}{ll}
- & \text { : Normal } \\
+ & \text { : Cell damage reaches } 25 \% \text { in eight fields of view } \\
++ & \text { : Cell damage reaches } 50 \% \text { in eight fields of view } \\
+++ & : \text { Cell damage reaches } 75 \% \text { in eight fields of view }
\end{array}
$$

Table 2: Kidney tubule damage level (Ghufron, 2001)

\begin{tabular}{cll}
\hline Damage Level & \multicolumn{1}{c}{ Proximal Contortus Tubule } & \multicolumn{1}{c}{ Distal Contortus Tubule } \\
\hline Normal & $\begin{array}{l}\text { Cells are not swollen, the cell core is } \\
\text { round, tubular lumen cells are clear }\end{array}$ & $\begin{array}{l}\text { Cells are not swollen, the cell core is } \\
\text { round, tubular lumen cells are clear }\end{array}$ \\
\hline Light & $\begin{array}{l}\text { Turbid swollen degeneration }+, \\
\text { hydropic degeneration }+, \text { tubular } \\
\text { lumen is not clear }\end{array}$ & $\begin{array}{l}\text { Turbid swollen degeneration }+, \\
\text { hydropic degeneration }+, \text { tubular } \\
\text { lumen is not clear }\end{array}$ \\
\hline Moderate & $\begin{array}{l}\text { Turbid swollen degeneration }++, \\
\text { hydropic degeneration }++, \text { fatty }+,\end{array}$ & $\begin{array}{l}\text { Turbid swollen degeneration }++, \\
\text { hydropic degeneration }++, \text { fatty }+, \\
\text { tubular lumen is not clear }\end{array}$ \\
& tubular lumen is not clear & $\begin{array}{l}\text { Turbid swollen degeneration }+++, \\
\text { hydropic degeneration }+++, \text { fatty } \\
+ \text { Severe }\end{array}$ \\
& $\begin{array}{l}\text { Turbid swollen degeneration }+++, \\
\text { hydropic degeneration }+++, \text { fatty } \\
\text { there is necrosis cell }\end{array}$ \\
&,++ tubular lumen is not clear, there \\
& is necrosis cell &
\end{tabular}

Explanation:

- : Normal

$+\quad$ : Cell damage reaches $25 \%$ in eight fields of view

$+\quad$ : Cell damage reaches $50 \%$ in eight fields of view

$+++\quad$ : Cell damage reaches $75 \%$ in eight fields of view

\section{Results and Discussion}

\section{The observation of kidney anatomical change}

The study was conducted to observe the pathological change of green iguanas' kidney after feeding with red spinach. Spinach contained vitamin A, B, C, E, and K, iron, manganese, phosphorus, zinc, protein, purine, fat, carbohydrates, flavonoids, amarantin, potassium, selenium, niacin, beta-carotene, omega-3 fatty acids, Fiber, neoxanthin, violaxanthin, lutein, zeaxanthin, angiotensin, and antioxidants (Nuraini, 2014). On the other hand, spinach also contained substances that were harmful if consumed too much, among others, was oxalate and purine. Oxalic acid and its water-soluble salts may be dangerous because they were toxic (Fitriani et al., 2016). Purine content if the metabolism process was disturbed then the level of uric acid in the blood would increase and composed uric acid crystals (Zakhia, 2015). The most common damage would increase in the urinary system. The kidneys were an essential organ for ensuring the exact composition of blood and extracellular fluids, with the primary task being to excrete ingredients that the body no longer needed in the urine. Urine was the main path of excretion of toxicants. As a result, the kidney had a high blood flow volume to concentrate toxicity (Mangindaan et al., 2014). As clearly shown in table 3 explained the observation result of kidney anatomy structure change. Based on the observation result of 30 day treatment, all iguanas on group P1, P2, and P3 with 1.5 grams/ day/ head, 3 grams/ day/ head, and 6 gram/ day/ head red spinach dose each orally had red, long, and lobed kidneys located at the beginning of the tail from the back legs, and also the consistency was chewy (Figure 1). Green iguanas had a pair of lobed reddish-brown kidneys that located on the pelvis, attached to the dorsal of the body wall, and caudal kidney expanded to the beginning of the tail (Girling, 2003; Hernandez-Diver, 2003). However, in this study, there was anatomical change in the form of enlargement of kidney size. The average length and width of kidney were $0.8 \mathrm{~cm} \times 0.3 \mathrm{~cm}$ on 
the control group (P0), $1.6333 \mathrm{~cm} \times 0.4 \mathrm{~cm}$ on group P1, $1.9 \mathrm{~cm} \times 0.5667 \mathrm{~cm}$ on group P2, and $2.1667 \mathrm{~cm} \times 0.7 \mathrm{~cm}$ on group P3. Kidney size changing grew as the increasing of the given red spinach doses.
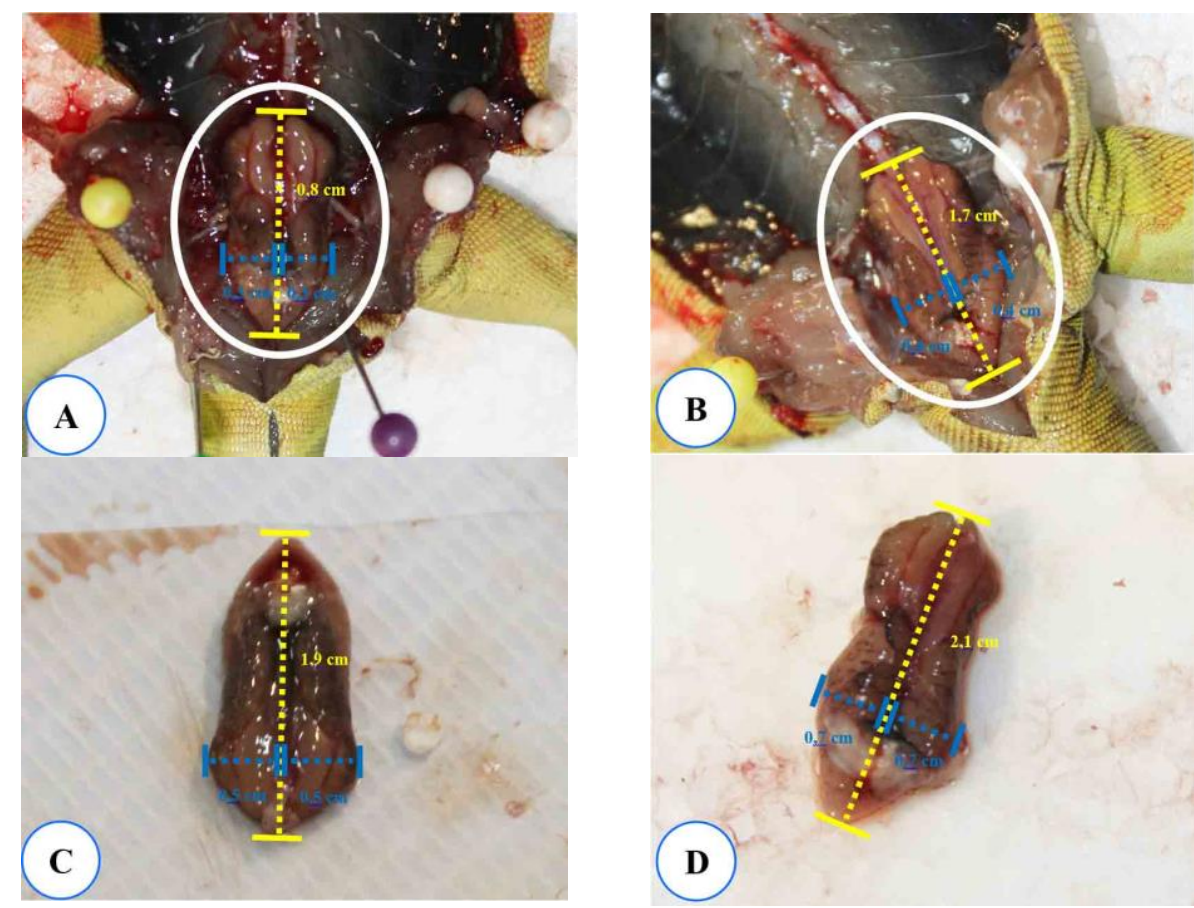

Figure 1: Green iguana's kidney (white circle) in control group (A), Treatment group I (B), Treatment group II (C), Treatment group III (D).

Table 3: Observation result of kidney anatomy structure change

\begin{tabular}{cccccc}
\hline \multirow{2}{*}{ Groups } & \multicolumn{5}{c}{ Kidney Anatomy Structure } \\
\multicolumn{2}{c}{ Measurement $(\mathrm{cm})$} \\
\cline { 2 - 5 } & \multirow{2}{*}{ Colors } & Shapes & Consistency & Length & Width \\
\cline { 5 - 6 } P0.1 & Red & Long and lobed & Chewy & 0,8 & 0,3 \\
P0.2 & Red & Long and lobed & Chewy & 0,7 & 0,3 \\
P0.3 & Red & Long and lobed & Chewy & 0,9 & 0,3 \\
P1.1 & Red & Long and lobed & Chewy & 1,5 & 0,4 \\
P1.2 & Red & Long and lobed & Chewy & 1,7 & 0,4 \\
P1.3 & Red & Long and lobed & Chewy & 1,7 & 0,4 \\
P2.1 & Red & Long and lobed & Chewy & 2 & 0,6 \\
P2.2 & Red & Long and lobed & Chewy & 1,9 & 0,5 \\
P2.3 & Red & Long and lobed & Chewy & 1,8 & 0,6 \\
P3.1 & Red & Long and lobed & Chewy & 2,2 & 0,7 \\
P3.2 & Red & Long and lobed & Chewy & 2,1 & 0,7 \\
P3.3 & Red & Long and lobed & Chewy & 2,2 & 0,7 \\
\hline
\end{tabular}

ANOVA result showed significant difference towards the length and the width changes of green iguanas' kidney with $\mathrm{p}$-value $=0.000(\mathrm{p}<0.05)$ and proceeded to Post Hoc test to score the difference between the control group and the treatment groups (P1, P2, and P3) where there was also significant difference found. The significant length change was between group PO and P1 $(p=0.83333)$, PO with P2 $(p=1.10000)$, PO with P3 ( $p=1.36667)$, P1 with P2 ( $p=$ $0.26667)$, P1 with P3 ( $p=0.53333)$, and P2 with P3 ( $p=0.26667)$. The significant width change was between P0 with P1 $(p=0.10000)$, PO with P2 $(p=0.26667)$, PO with P3 $(p=$ $0.40000)$, P1 with P2 ( $p=0.16667)$, P1 with P3 ( $p=0.30000)$, and P2 with P3 ( $p=0.13333)$. Kidney size enlargement was presumed to be theresult of the excessive chemical substances in 
the red spinach that caused kidney glomerulus to work hard to filter substances that entered the body.

The result comparison of green iguanas' kidney necropsy on thecontrol group (PO) with the reference was relatively similar. Both the control group (PO) and the reference had long lobed kidneys; only they had slightly different colors. On the control group (PO), the kidney looked brighter red than the one on the reference. But they were still in the normal range (Figure 2).
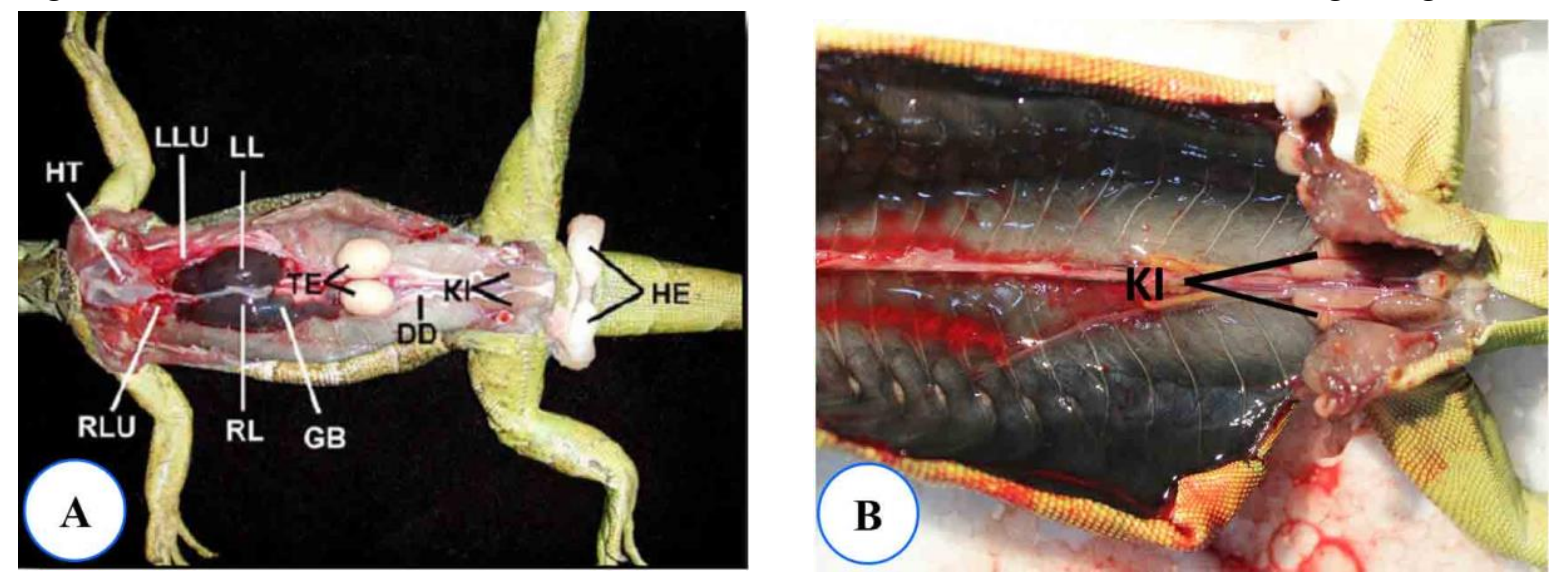

Figure 2: Green iguanas' kidney comparison according to Jacobson (2007) (Fig. A) and the research in the control group (Figure-B). (KI) Kidneys, (DD) Ductus deferens, (GB) Gallbladder, (HE) Hemipenes, (HT) Heart, (LL) Left liver lobe, (LLU) Left lung, (RL) Right liver love, (RLU) Right lung, (TE) Testes

\section{Observation of Kidney Histological Change}

\section{Control Group}

After the observation, no histological changes were found in the control group which was given collard and aquadest (Figure 3). Glomerulus was a tight capillary sphere (capillary of glomerulus) that branched from afferent arterioles which went into nephrons. Bowman's capsule was acup-like body which went around the glomerulus and collected materials (filtrate) that were pushed from capillary of the glomerulus. Bowman's capsule consists of the parietal layer and visceral layer. Parietal layer (PL) from Bowman's capsule that surrounded glomerulus (GL) consists of cuboid cells (Girling, 2003). Proximal tubules (PT) had epithelial cells with eosinophilic cytoplasm, and distal tubules had epithelial cells with basophilic cytoplasm (Jacobson, 2007).
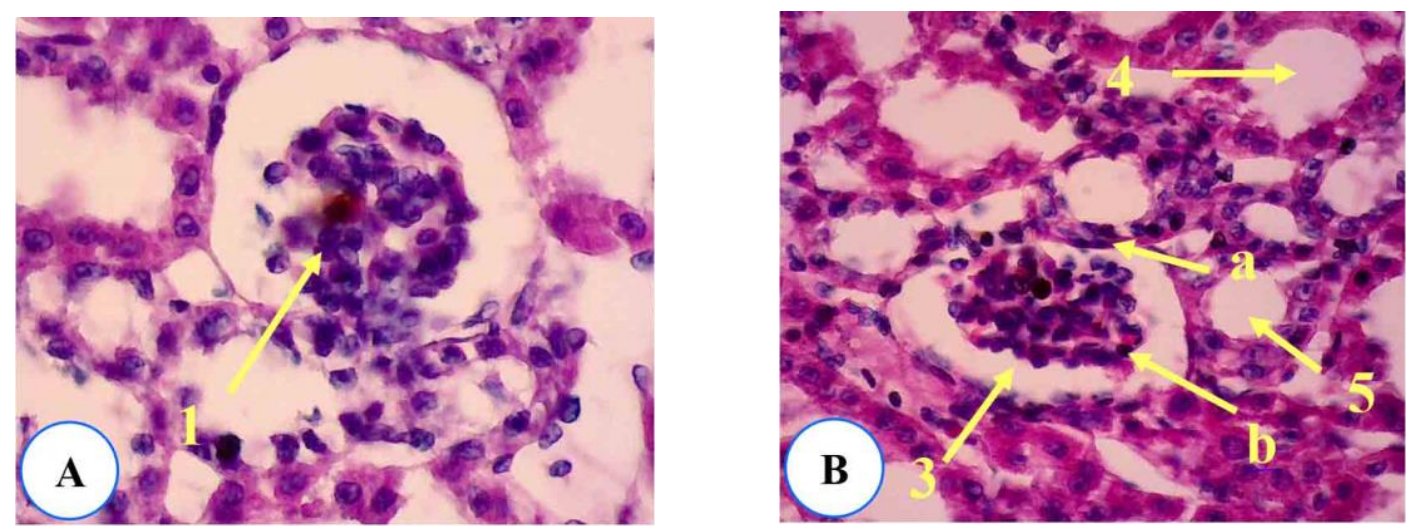

Figure 3: Histology image of thegreen iguanas control group (A and B). (1) Glomerulus, (2) Bowman's capsule (a) parietal layer, (c) visceral layer, (3) Bowman's space, (4) proximal tubule, (5) distal tubule. H\&E X 400. 


\section{Treatment Group}

\section{tructure Change}

Glomerulus enlargement and capsular space constriction: In the treatment group I, glomerulus seemed to grow bigger with light damage level, and treatment group II showed moderate damage level. Treatment group III showed severe damage level that was indicated by the enlargement of glomerulus that grew bigger than other treatment groups that the capsular space constricted more and more (Figure 4). This was presumed to be caused by excessive chemical substances in the red spinach that formed antibody as a respond to antigen inside the body. This caused the formation of complex antigen-antibody which stuck in glomerular chunks, or in a few cases this antigen heaped on the wall of the glomerular capillary that caused inflammation and made glomerulus not work properly (Snell, 2006).
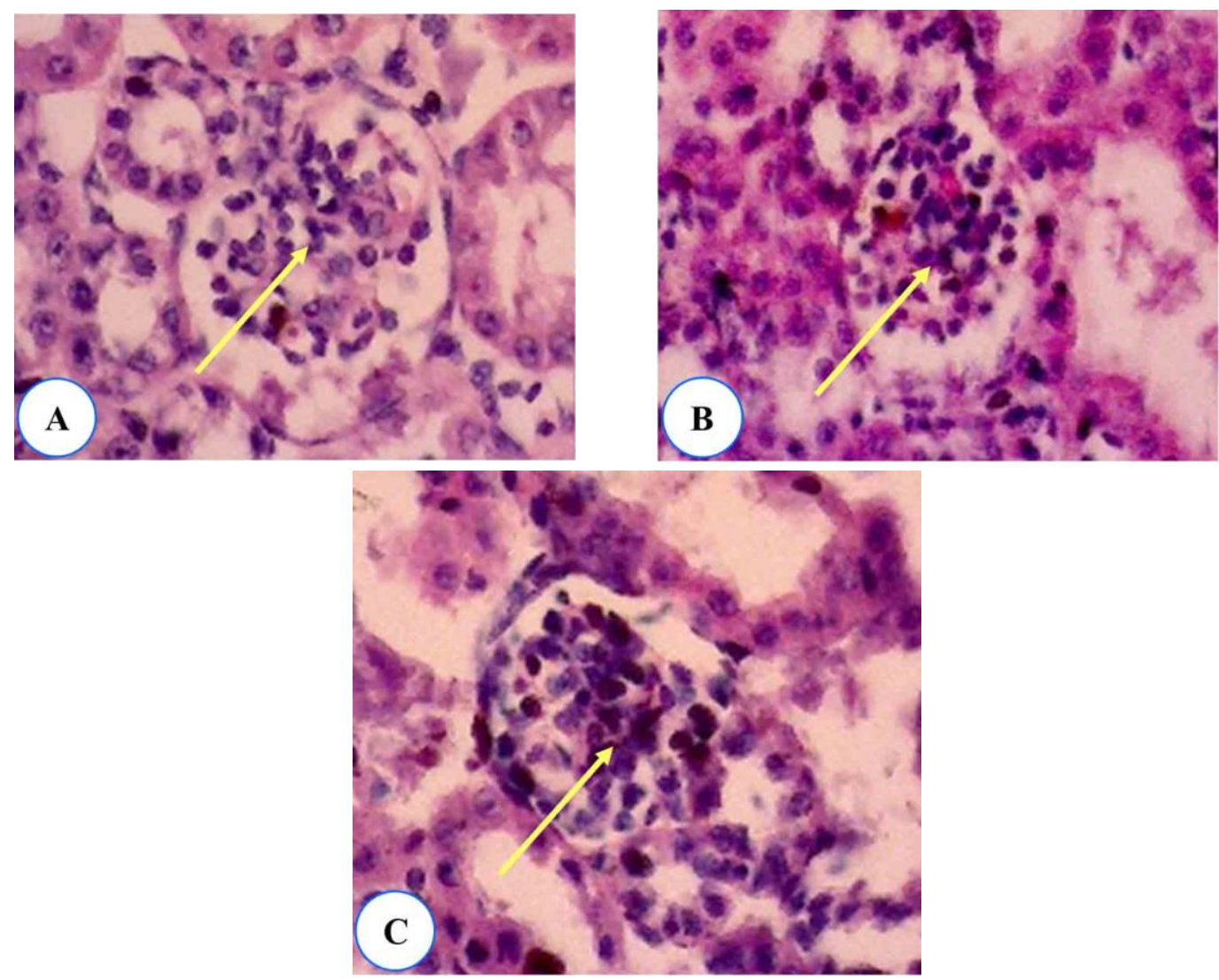

Figure 4: The glomerulus enlargement (yellow arrow) in the treatment group I (A), treatment group II (B), treatment group III (C), H\&E X 400.

Hydropic degeneration: Treatment group I, II, and IIIwere given 25\%, 50\%, and 100\% red spinach dose each and sacrificed on the $31^{\text {st }}$ day. It looked that tubules underwent hydropic degeneration (Figure 5). The presence of cellular swell, empty spaces (vacuoles), enlarged and docked cells was indicative of the occurrence of hydropic degeneration. Hydropic degeneration was a reversible cell injury with more severe intracellular accumulation when albumin was followed. Hydropic degeneration occurred in epithelial cells (Suhita et al., 2013). Damage occurred to mitochondria cells. Changes in the permeability of cell membranes to other substances could be generated by toxic substances. Degeneration with an indestructible factor would continue in necrosis (Widyanti, 2013). 

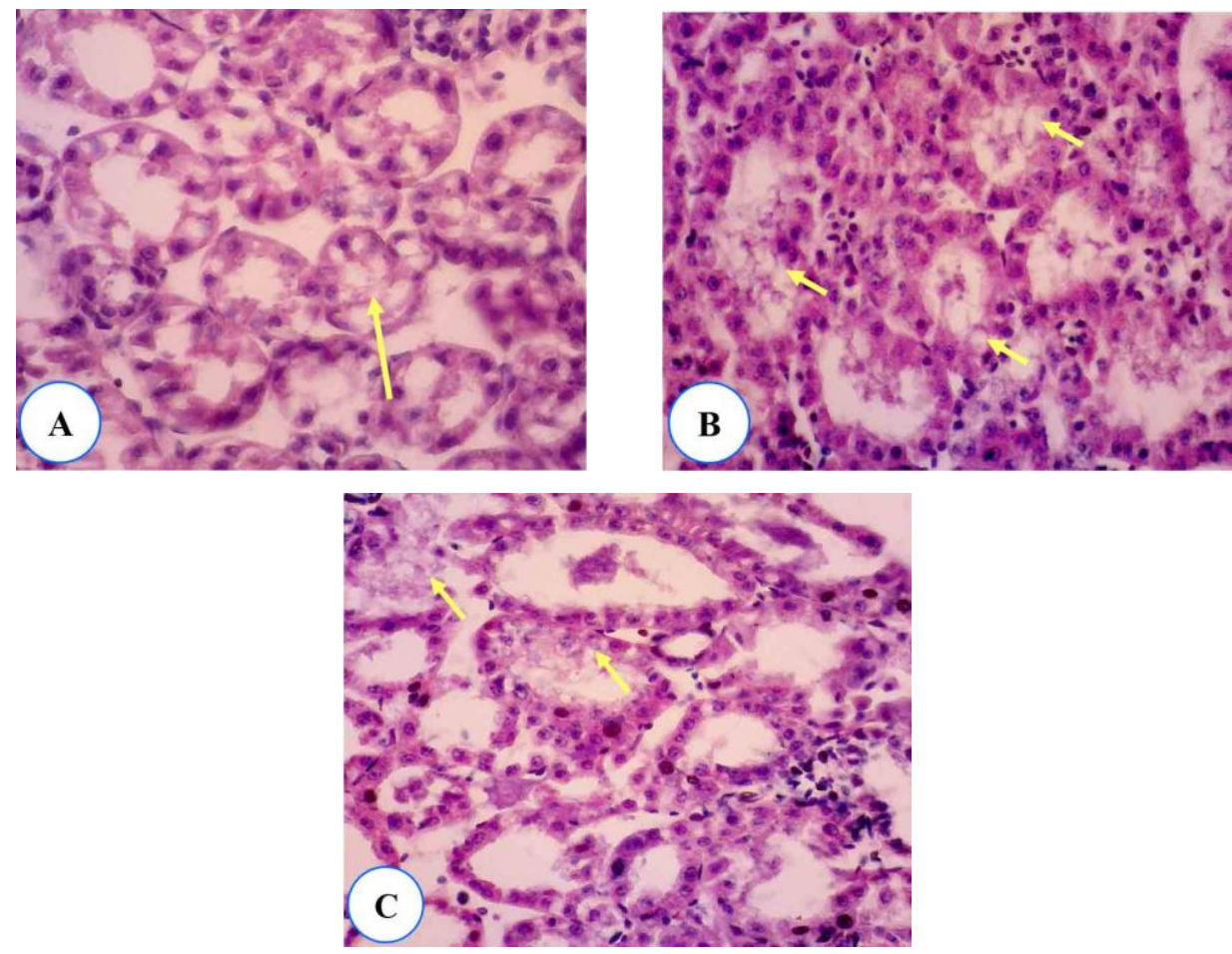

Figure 5: Hydropic degeneration (yellow arrow) in the treatment group I (A), treatment group II (B), treatment group III (C), H\&E X 400.

The treatment group I was given $25 \%$ red spinach seemed to have fewer tubules which underwent hydropic degeneration compared to treatment group II. Treatment group III that was given $100 \%$ red spinach seemed to have more hydropic degeneration than treatment group 1 and 2 . This possibly occurred because this group was fed more red spinach than other treatment groups.

Tubular dilation: Based on the observation in treatment group I, II, and III with 25\%, 50\%, and $100 \%$ red spinach each dose, it was found that there was a change which was tubular dilation (Figure 6). Tubular dilation was an expansion or stretching of tubules structure. On treatment group III, the tubular lumen expanded more than treatment group I and II. Tubular dilation grew as the increasing of the given red spinach doses. Tubular dilation was caused by urine retention or inflammation in renal interstitium area. Dilation could be seen with lumen expansion although the tubular epithelial was still normal. Tubules with dilation condition would suffer lysis, hypoxia, and death (Fatonah, 2015).

Necrosis: On treatment group I, II, and III, red spinach dose was given for $25 \%, 50 \%$, and $100 \%$ each and it looked like tubules underwent necrosis (Figure 7). Necrosis was the death of cells and tissues on the body of the living creature. On necrosis, the change looked real in the nucleus (cells core). Necrosis started with morphology change in cell core namely pyknosis. The next step, the core broke (karyorrhexis) and disappeared (karyolysis) (Price and Wilson, 2006). Kidney damage in the form of tubular necrosis was caused by some organic toxins. This occurred because the epithelial cells were in direct contact with the reabsorbed material, so that the renal tubule epithelial cells may undergo necrosis in the cell nucleus (Fitria, 2015). 

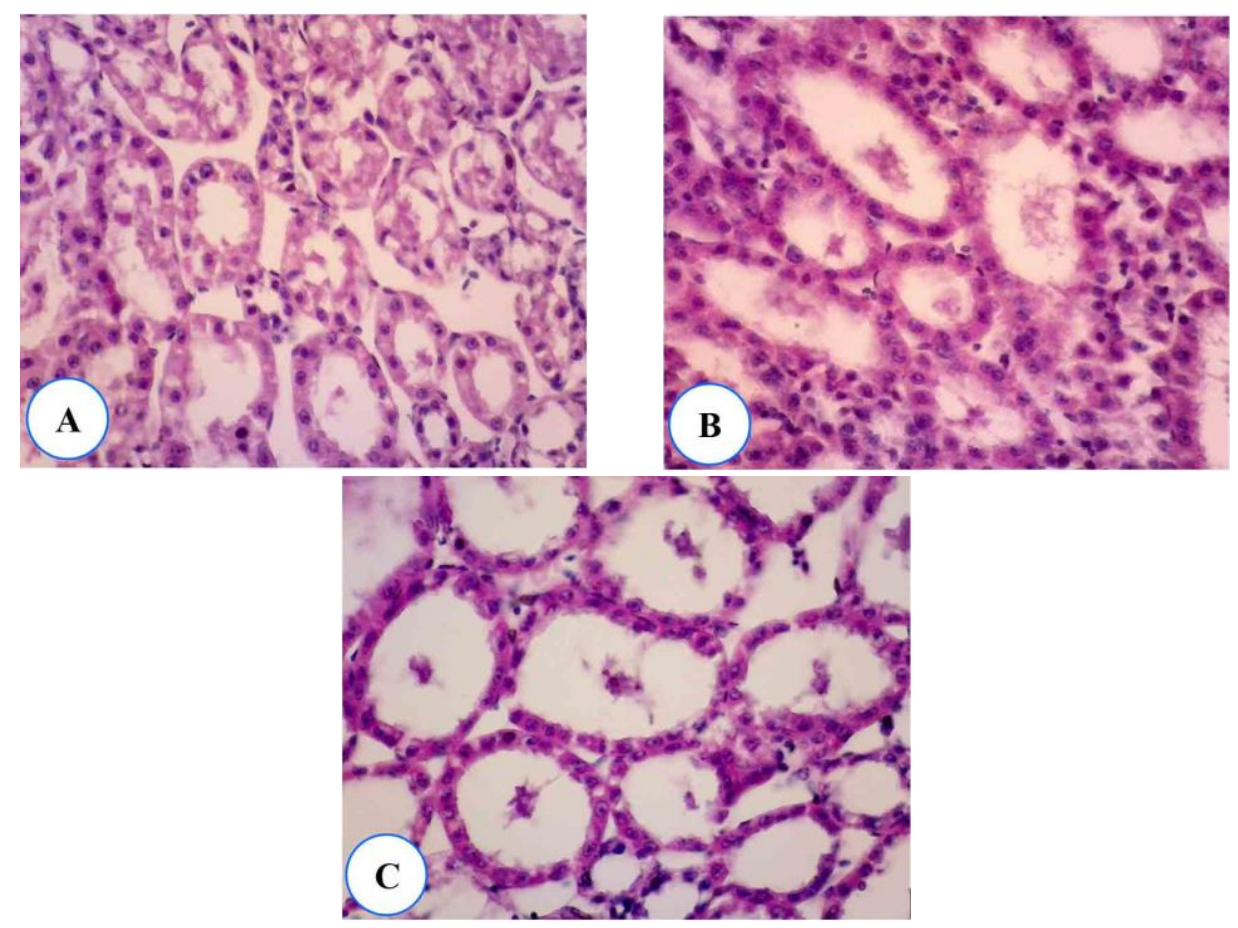

Figure 6: Tubules dilation in treatment group I (A), treatment group II (B), treatment group III (C), H\&E X 400.
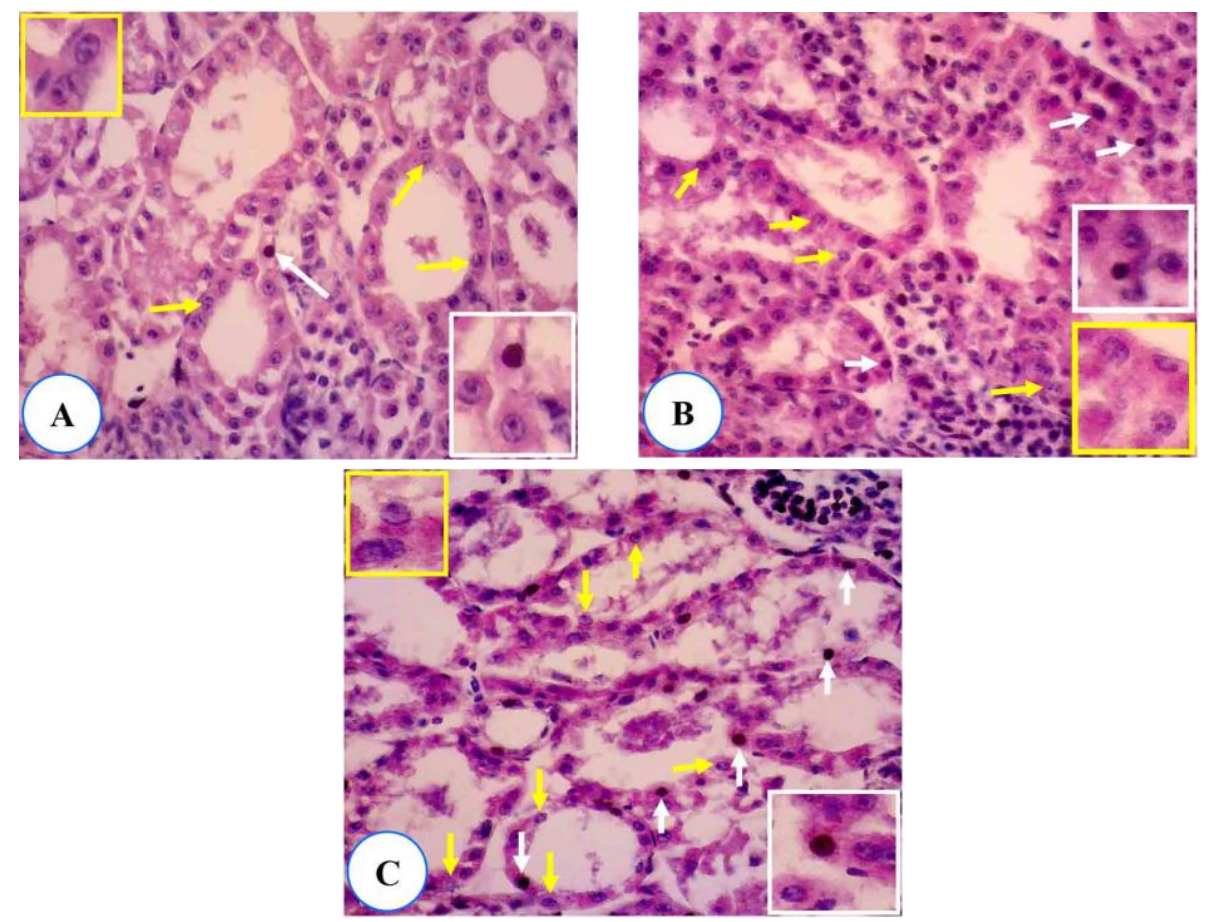

Figure 7: Necrosis (yellow arrow) and apoptosis (white arrow) in the treatment group I (A), treatment group II (B), treatment group III (C), H\&E X 400 .

If a chemical was secreted actively from blood to urine, chemicals were first accumulated in the proximal tubule. As a result of the concentration process, these toxic substances would accumulate in the kidney and caused damage to the kidneys (Suhita et al., 2013). The kidney was a vital organ that plays a very important role in maintaining environmental stability in the 
body with the main function of filtration by glomerulus, reabsorption and tubular secretion. Renal cell damage until cell death would lead to impaired renal function (Windhartono et al., 2013). Moreover, there was also apoptosis or the death of programmed cells which was the normal component on the development and the maintenance of health in multicellular organisms (Figure 7).

Fibrosis: The change that was foundin interstitium treatment group I, II, and III was the formation of connective tissues (fibrosis) (Figure 8). Fibrosis was a condition where the formation of excessive fibrous connective tissues occurred in an organ or tissue due to inflammation so that fibrosis played an important role in the progression of chronic disease. Inflammatory reactions may lead to macrophage activation, then $\mathrm{NfkB}$ became more active, thus anexpression of pro-inflammatory cytokines such as TNF- $\alpha$, IL-1 or IL- 6 . It would also express TGF- $\beta 1$ (Anindita et al., 2017). TGF- $\beta 1$ would stimulate target cells, namely fibroblast cells, mesangial cells, podocytes, tubular cells and endothelial cells. Activation of these target cells would trigger the formation of ECM. The fibroblast cells would express type I collagen and eventually led to interstitial fibrosis of the kidneys. Excessive production of collagen was a major contributor to renal fibrosis regulated by fibrogenic factors such as TCF- $\beta 1$ (Cheng et al., 2013). Different types of renal cells underwent different pathophysiological changes due to induction of TGF- $\beta 1$, which caused apoptosis, hypertrophy and Podocyte process disorder, leading eventually to renal dysfunction (Loeffler and Wolf, 2014).
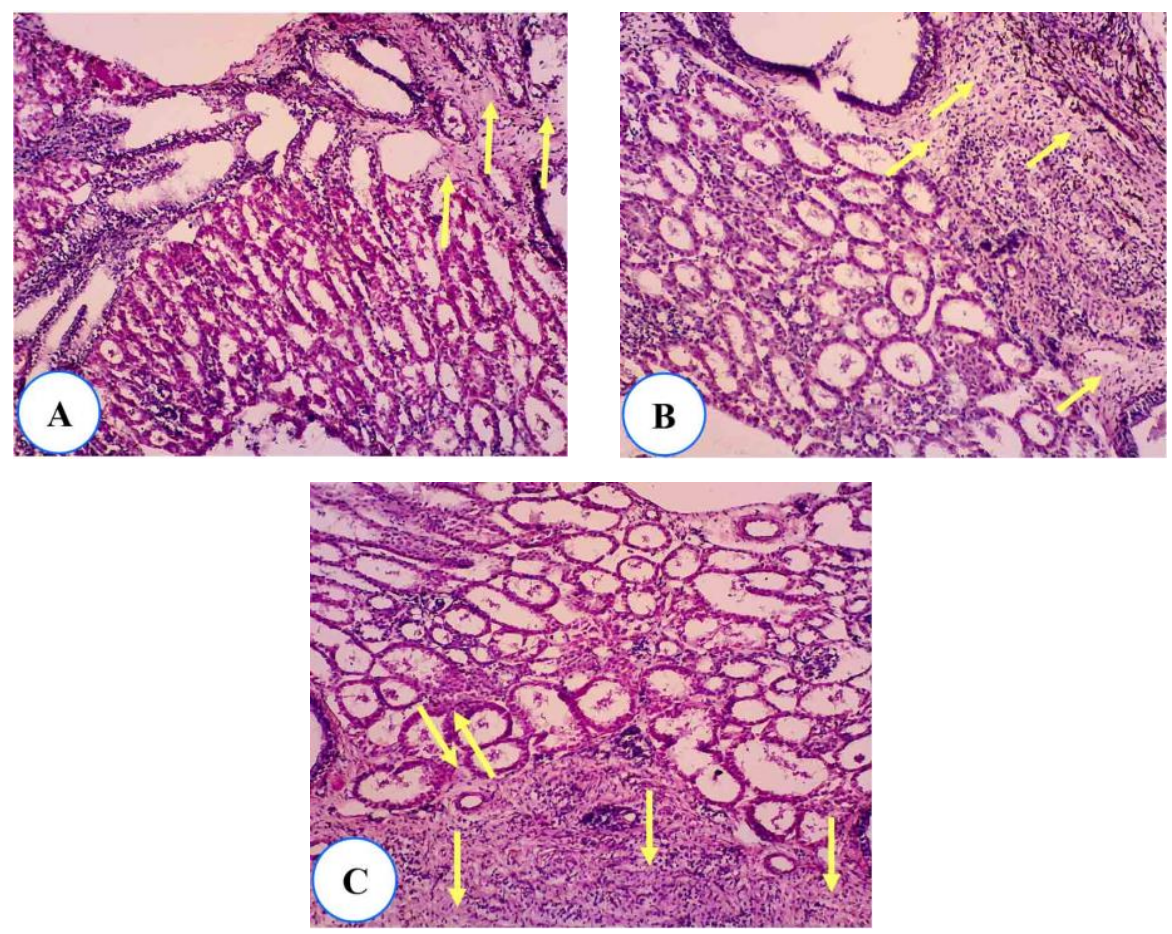

Figure 8: Fibrosis in therenal interstitium (yellow arrow) in the treatment group I (A), treatment group II (B), treatment group III (C), H\&E X 100.

\section{Accumulation on kidney}

Uric acid crystal: Uric acid was the end product of purine metabolism. Purines (adenine and guanine) were nucleic acid contents (Kurniawan, 2015). Purines were one of the basic organic compounds that made up the nucleic acids (nucleic acid of the cell) that belong to the amino acid group, the protein-forming element (Wahyuningsih, 2013). Purine rotation occurred 
continuously in the body along with the synthesis and decomposition of DNA and RNA, although no purine intake would still form substantial uric acid. Uric acid was synthesized primarily in the liver by the enzyme xanthine oxidase (Kurniawan, 2015).

There were fragments of crystal or uric acid sediment in tubular lumen of treatment group I, II, and III. Treatment group I that was given $25 \%$ of red spinach had less uric acid crystal sediment compared to treatment group II and III with $50-100 \%$ red spinach doses. Uric acid crystal sediment increased as the increasing of given red spinach doses (Figure 9). The uric acid crystal sediment in the renal tubular lumen was caused by glomerulus filtration disturbance. The formation of gout couldbe caused by the consumption of food which contained high purine level and the uric acid disposal system through urine did not work properly. This disease began from kidney damage which was the decreasing of glomerulus function in filtering metabolism wastes. As a result, the uric acid level in blood increased that was known as hyperuricemia. The increasing of uric acid that happened continuously resultedin sedimentation of uric acid in various organs (Choi et al., 2005). Kidney damage could be caused by renal obstruction and urinary system blockage.
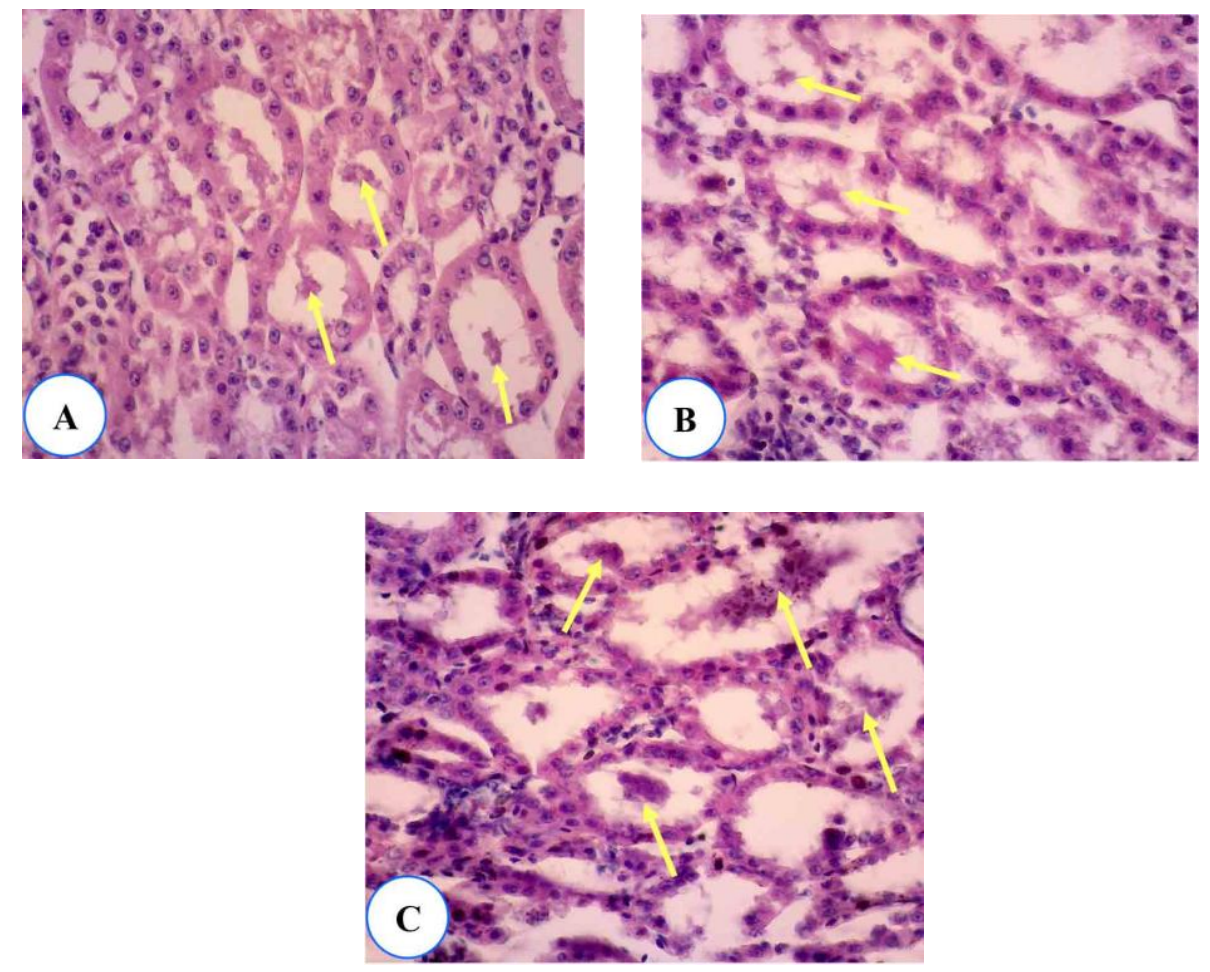

Figure 9: Uric acid crystals (yellow arrow) in thetubular lumenin the treatment group I (A), treatment group II (B), treatment group III (C), H\&E X 400 .

Iguanas were included as uricotelic that excreted metabolism protein into uric acid (Guyton, 2006). However, since kidney damage caused uric acid could not be excreted properly that resulted in sediment appearance in all renal parenchyma. During the process of histology, many nerves disappeared, but the traces of their existence looked very clear as amorphous blue material or basophilic crystals which appear like balls or stars under the microscope.

Oxalate crystal: On tubular lumens of treatment group I, II, and III, there was crystal sediment which was presumed to be oxalate crystals (Figure 10). On treatment group I that was given $25 \%$ of red spinach, there was crystal sediment which was relatively small and less compared to treatment group II and III with $50-100 \%$ of red spinach doses each. The formed crystal sediment on treatment group II had identical size with the one on treatment group III. The 
formation of oxalate crystal sediment in tubular lumen was caused by the high amount of oxalate in red spinach. Oxalate acid and its water-soluble salts may be dangerous because they were toxic. High oxalic acid content in the body could be harmful because the oxalate content was too high to interfere with renal function (Fitriani et al., 2016). Inside the body, oxalate would be compounded with calcium to form crystals called calcium oxalate. The crystal would precipitate and if collected would enlarge to form kidney stones (Lingga, 2010).
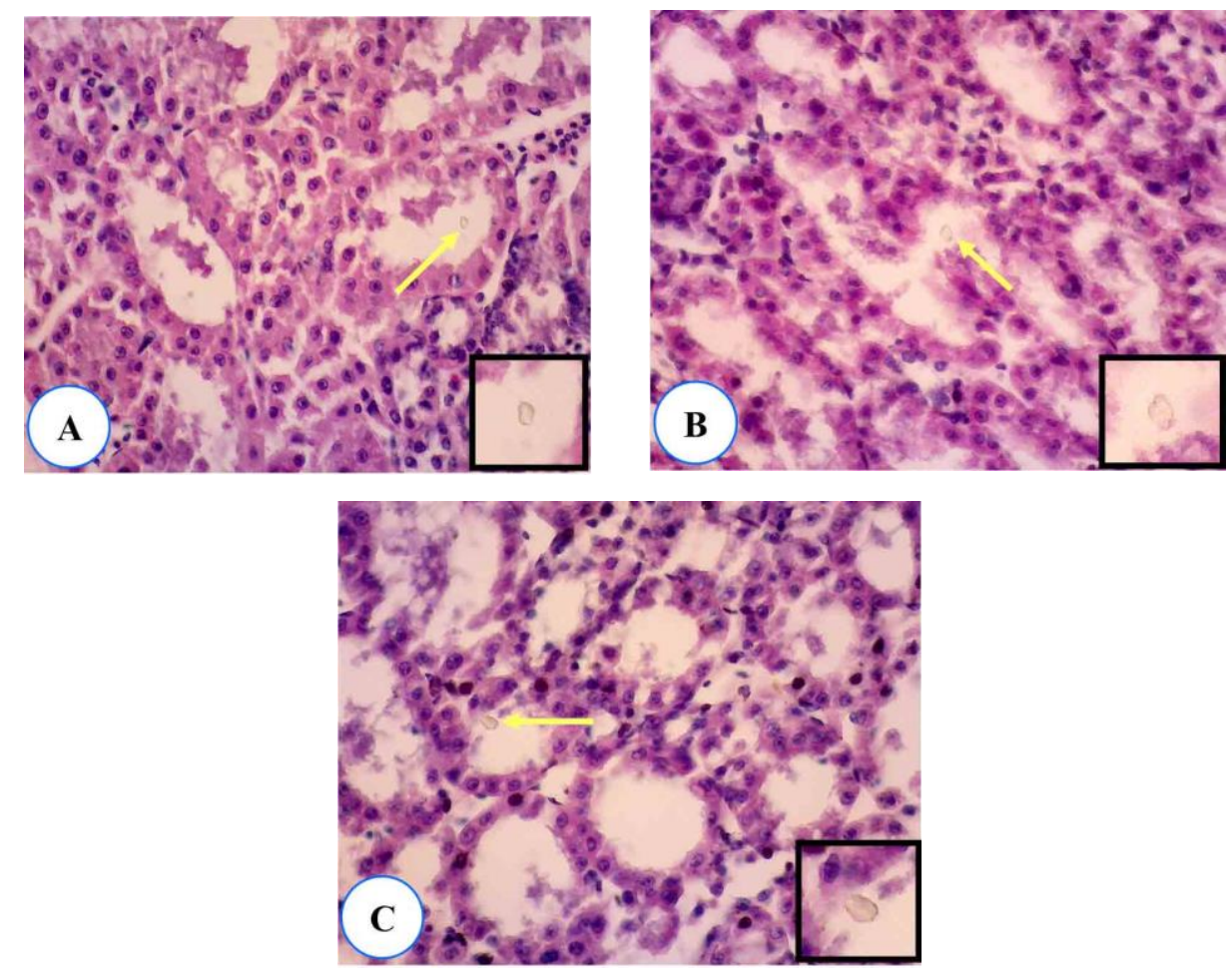

Figure 10: Oxalate crystals (yellow arrow) in thetubular lumenin treatment group I (A), treatment group II (B), treatment group III (C), H\&E X 400.

Lymphocyte: Treatment group I, II, and III were given 25\%, 50\%, and $100 \%$ of red spinach doses each, and there was lymphocyte infiltration in the interstitium (Figure 11). This was caused by inflammation. On treatment group III, there were more lymphocytes than on treatment group I and II. This was presumed to be the cause of chemical substances in red spinach that must be phagocytized by lymphocyte compared to the other groups. Leukocyte cell infiltration was the release of leukocyte cells from blood vessels to areas that had cell necrosis to assist in the process of phagocytosis (inflammatory process). It was characterized by the appearance of large numbers of cells, tightly coated with each other and more purple than tubular epithelial cells (Windhartono et al., 2013).

The Effect Of Feeding Red Spinach (Amaranthus tricolor L.)Towards The Renal Histology Change Of Green lguanas: Based on the observation result of green iguanas renal histopathology image after being given $25 \%, 50 \%$ and $100 \%$ of red spinach doses caused kidney damage in the form of glomerulus enlargement, capsular space constriction, hydropic degeneration, tubular dilation, necrosis, the formation of connective tissues (fibrosis), uric acid crystal sediment (gout), oxalate crystal, and lymphocyte infiltration. The occurring damages were similar. The differences were only located to the damage levels from each group as shown in table 4. 

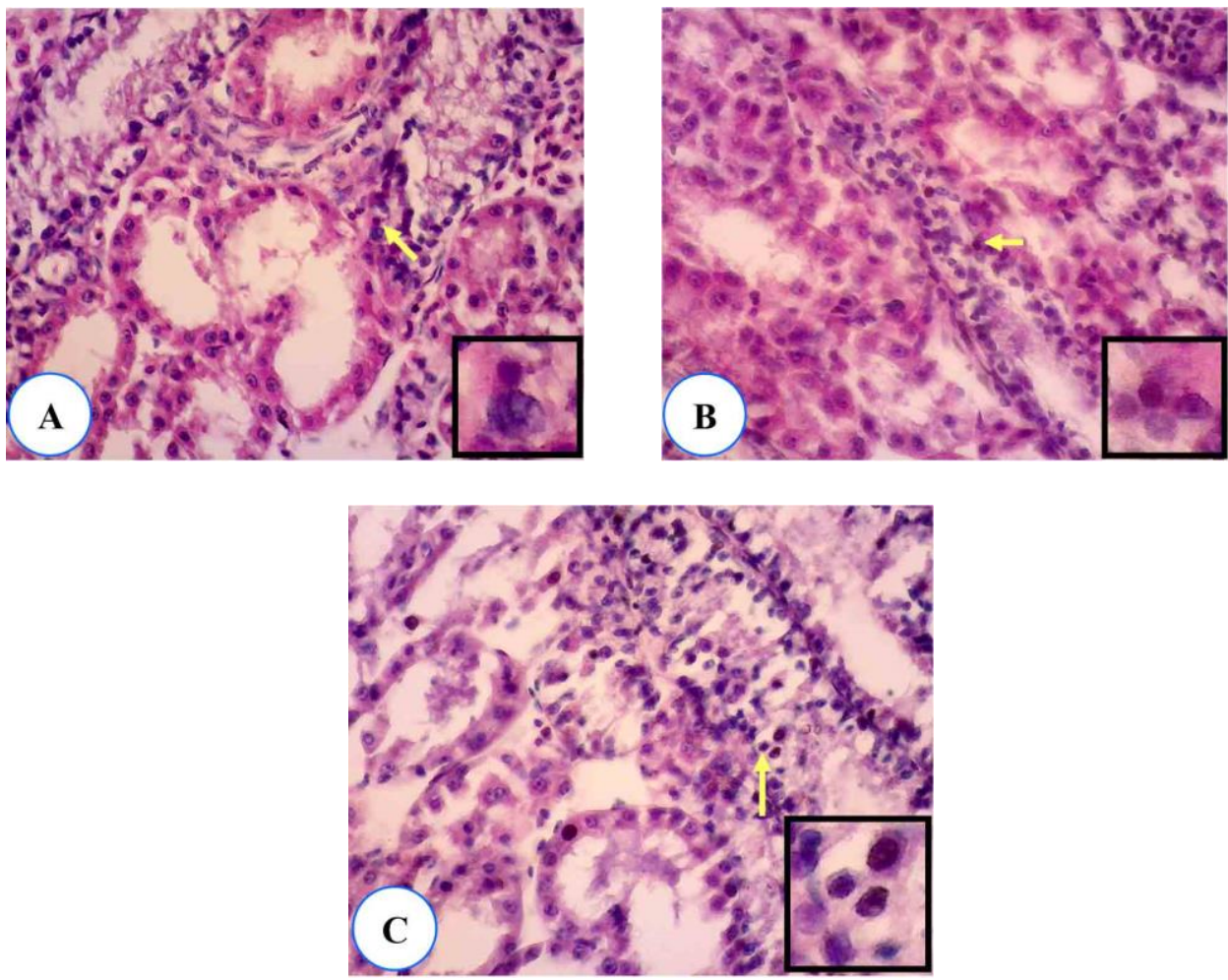

Figure 11: Lymphocyte (yellow arrow) in treatment group I (A), treatment group II (B), treatment group III (C), H\&E X 400.

Table 4: Green iguanas' renal histopathology damage levels after being fed with red spinach orally with different doses.

\begin{tabular}{|c|c|c|}
\hline Treatment Groups & Damage Levels & Explanation \\
\hline Control group & Normal & Renal cells are normal \\
\hline Group P1 & Light & $\begin{array}{l}\text { Glomerulus enlargement }+ \text {, capsular space } \\
\text { constriction }+ \text {, hydropic degeneration }+ \text {, tubular } \\
\text { dilation }+ \text {, necrosis }+ \text {, fibrosis }+ \text {, uric acid crystal } \\
+ \text {, oxalate crystal }+ \text {, lymphocyte }+\end{array}$ \\
\hline Group P2 & Moderate & $\begin{array}{l}\text { Glomerulus enlargement }++ \text {, capsular space } \\
\text { constriction }++, \text { hydropic degeneration }++, \\
\text { tubular dilation }++, \text { necrosis }++ \text {, fibrosis }++ \text {, uric } \\
\text { acid crystal }++ \text {, oxalate crystal }++ \text {, lymphocyte } \\
++\end{array}$ \\
\hline Group P3 & Severe & $\begin{array}{l}\text { Glomerulus enlargement }+++ \text {, capsular space } \\
\text { constriction }+++ \text {, hydropic degeneration }+++ \text {, } \\
\text { tubular dilation }+++ \text {, necrosis }+++ \text {, fibrosis }+++ \text {, } \\
\text { uric acid crystal }+++ \text {, oxalate crystal }+++, \\
\text { lymphocyte }+++\end{array}$ \\
\hline
\end{tabular}

\section{Conclusion}

The result of this study can be concluded that feeding red spinach caused renal anatomy and histological change of green iguanas. Severe damage occurred to the treatment group III with $100 \%$ of red spinach dose. Moderate damage occurred to the treatment group II with $50 \%$ of 
red spinach dose, and light damage occurred to the treatment group I with $25 \%$ of red spinach dose.

\section{Acknowledgments}

The authors thank all members of the Veterinary Teaching Clinic of Medical Faculty of the University of Hasanuddin for helping and facilitating the authors during this experiment. The authors state there is no conflict of interest with the parties concerned in this research.

\section{References}

Anindita, R., Purwanto, B., Sugiarto. 2017. The effect of vitamin D3 (calcitriol) on levels TGF $\beta 1$ and IL-6 in fifth gade chronic kidney disease patients grade V. Biomedika. 9 No. 1: 813. DOI: https://doi.org/10.23917/biomedika.v9i1.4341.

Anonymous. 2013. Anatomy of animals. Directorate of Vocational Secondary School Development of the Ministry of Education and Culture of the Republic of Indonesia. Accessed on January 9, 2016 at wWW. BSE.Mahoni.com.

Bacha, WJ., Bacha, LM. 2000. "Colour atlas of veterinary histology". United Stated of America: Lippincot Williams and Wilkins.

Cheng, X., Gao, W., Dang, Y., Liu, X., Li, Y., Peng, X., Ye, X. 2013. Both ERK/MAPK and TGFBeta/Smad signaling pathways pathway play a role in the kidney fibrosis of diabetic mice accelerated by blood glucose fluctuation. J. Diabetes Res. 13: 1-8.

Choi, HK., Mount, DB., Reginato, AM. 2005. Pathogenesis of uric acid. Ann. Intern. Med. 143: 499-516.

Fatonah, YNN. 2015. Pathomorphology study of gout case and uremia syndrome in komodo (Varanus komodoensis) in captivity. Bogor: Faculty of Veterinary Medicine, Bogor Agricultural University.

Fitria, A. 2015. Effect of dexamethasone on male rats. Malang: FMIPA UM.

Fitriani, H., Nurlailah, Rakhmina, D. 2016. The content of oxalic acid vegetable spinach. Medical Laboratory Technology Journal. 2: 51-55.

Ghufron, M.. 2001. An overview of the histologic structure of liver and rat rats after treatment implanted ginger root (Zingiber officinale) in graded doses. Yarsi Medical Journal. 9: $72-$ 88.

Girling, S., 2003. "Veterinary nursing of exotic pets". UK: Blackwell Publishing.

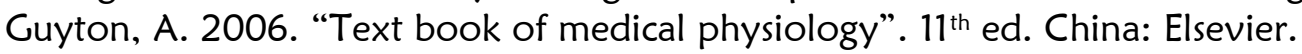

Hernandez-Diver, S.J., 2003. Green iguana nephrology: A review of diagnostic techniques. Vet. Clin. Exot. Anim., 6: 233-250.

Jacobson, ER. 2007. "Infectious diseases and reptile pathology". USA: CRC Press.

Kurniawan, FB. 2015. "Clinical chemistry: Health analysis practice". Jakarta: ECC.

Lingga, L. 2010. “Intelligent to choose vegetables”. Jakarta: PT Agromedia Pustaka.

Loeffler, I., Wolf, G. 2014. Transforming growth factor-beta and the progression of renal disease. Nephrology Dialysis Transplantation. 29 (Suppl_1): i37-i45. DOI: https://doi.org/10.1093/ndt/gft267.

Mangindaan, PY., Berata, IK., Setiasih, NLE. 2014. The effect of ethanol extract of the stem bark of moringa to the microscopic image of the mouse's kidney after being induced by alloxan. Indonesia Medicus Veterinus. 3: 142-146.

Nuraini, DN., 2014. "Various leaf nutritious for medicine". Yogyakarta: Gava Media.

Price, SA., Wilson, LM. 2006. "Pathophysiology: The concept of a clinical disease process". Jakarta: EGC.

Putranto, DI., Yuda, P., Zahida, F. 2013. The diversity of imported reptiles in Yogyakarta. Biota. 1: 117-125.

Snell, SR. 2006. “Anatomical Clinic for medical students. 1"st ed”. Jakarta: EGC. 
Suhita, NLPR., Sudiraand, IW., Winaya, IBO. 2013. Histopathological kidney of rat white the effect of the Pegagan extract against peroral. Udayana Veterinary Bulletin. 5 No.1: 6369.

Vosjoli, PD., Donoghue, S., Klingenberg, R., Blair, D. 2012. “Manual of green iguana”. California: Advanced Vivarium Systems.

Wahyuningsih, R. 2013. "Diet management in patients". Yogyakarta: Graha Ilmu.

Widyanti, IH. 2013. Case Report : The histopathological study of kidney in fruit bats in Gorontalo. Bogor: Bogor Agricultural University.

Windhartono, W., Kamal, Z., and Sasmito, E. 2013. The influence of carrot (Daucus carota L.) infusion on the histopathology of kidney male rats induced by uranium. Journal of Medicine Yarsi. 21: 033-040.

Zakhia. 2015. "Arthritis gout”. Accessed on July 25, 2017 at http//eprint.ums.ac.id. 